\begin{tabular}{|c|c|c|}
\hline & Int.J.Curr.Microbiol.App.Sci (2021) 10(08): 99-106 & \\
\hline & $\begin{array}{l}\text { International Journal of Current Microbiology and Applied Sciences } \\
\text { ISSN: 2319-7706 Volume } 10 \text { Number } 08 \mathbf{( 2 0 2 1 )} \\
\text { Journal homepage: } \underline{\mathrm{http}: / / \text { ww.ijcmas.com }}\end{array}$ & $\begin{array}{l}9 \\
-9\end{array}$ \\
\hline $\begin{array}{l}\text { EXCELLENT } \\
\text { PUBLISHERS }\end{array}$ & & wuww.ijcmas.com \\
\hline
\end{tabular}

Original Research Article

https://doi.org/10.20546/ijcmas.2021.1008.013

\title{
Effect of the Application of Mycorrhizal Inoculation on Different Species of Echinacea
}

\author{
Asha Sharma ${ }^{1}$, Ishan Saini ${ }^{2 *}$ and Bandi Arpitha Shankar ${ }^{3}$ \\ ${ }^{1}$ Department of Agroforestry, G. B. Pant University of Agriculture and Technology, \\ Pantnagar, Uttarakhand - 263145, India \\ ${ }^{2}$ Department of Botany, Kurukshetra University, Kurukshetra 136118, Haryana, India \\ ${ }^{3}$ Acharya N G Ranga Agricultural University, Tirupati- 517502, Andhra Pradesh, India \\ *Corresponding author
}

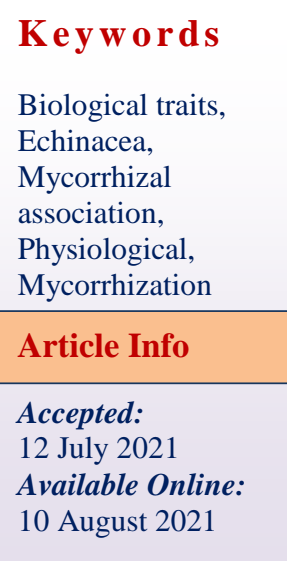

A B S T R A C T

The information regarding the effect of the mycorrhizal inoculation on different Echinacea species is not available in detail. Therefore, here we determined the changes in the biochemical composition of echinacea as a result of mycorrhizal inoculation. This experiment was undertaken to assess the effect of the mycorrhizal association on biochemical properties of different Echinacea species (E. angustifolia, E. purpurea, E. pallida). Here various echinacea species were inoculated with mycorrhiza to examine the species richness in different traits. The results established that biological traits (plant dry matter, chlorophyll content, carotenoid, $\mathrm{N}$ content, $\mathrm{P}$ content, K content). Among biochemical properties chlorophyll content, carotenoid and N, P, K were significantly higher under E. Purpurea than the E. angustifolia and E.pallida. Total dry matter was higher under $E$. angustifolia $(49.23 \mathrm{~g}$ ) and minimum dry matter was found under $E$. pallida(40.07 g). Overall, mycorrhizal inoculation is effective in improving Echinacea.

\section{Introduction}

Echinacea, also known as purple coneflower, is a member of the Asteraceae family. Botanically, echinacea is a perennial, herbaceous plant-primarily existing in eastern North America. Echinacea has an extended historical past of frequent use for an extensive range of illnesses. ${ }^{[1]}$ Medical studies validate a lot of conventional applications. It is probably one of the essential plant species that has more herbal healing value. The plant is used in standard cold, bronchitis, coughs, some inflammatory conditions, upper respiratory 
infections plus urinary tract infection. ${ }^{[2]}$ The oldest record of its medicinal uses dates back to the use by the North American Indians for managing the infections and wounds. Later, in the late $1800 \mathrm{~s}$, these echinacea formulations began being contemporary as remedies for the standard cold. ${ }^{[3]}$

Moreover, preparations also vary owing to variations within the plant part used, the method used for the biochemical compound extraction, the geographic location. ${ }^{[4]}$ Despite the variability among echinacea compounds, attempts have been made to standardize as well as to characterize the substance used in medical studies. ${ }^{[5]}$ The properties of phytochemical constituents of echinacea roots have been analyzed for several oxidative stresses, including various types of cancers. ${ }^{[6]}$ In recent years, echinacea items are among the best-selling medicinal health cures from the planet. The taxonomic category, identification and also phylogenetic connection of echinacea species were previously developed according to the morphological and phytochemical variation. $^{[7]}$ There are lots of parallels in morphology, physiology and chromosome quantity among echinacea species. ${ }^{[8]}$ Additionally, many species might have various ingredients with different effects that could decrease the security and usefulness of echinacea products. Consequently, it's imperative to identify the plant species employed for therapeutic purposes properly the amounts of these biochemicals can also be enhanced by metabolic engineering. ${ }^{\text {[9-11] }}$

In comparison to mutually advantageous mycorrhizal interactions, several mycoheterotrophic vegetation (approximately 400 plant species from various place families, pteridophytes, such bryophytes, as well as angiosperms) depend on mycorrhizal fungi for their $\mathrm{CO}_{2}$ resources. ${ }^{[12]}$ These plants have dropped their photosynthetic abilities and also parasitize mycorrhizal fungi which are connected with neighbor autotrophic vegetation. Arbuscular mycorrhizal fungi colonize the origins of numerous agriculturally crucial meal and bioenergy plants and may perform as' biofertilizers and bioprotectors' in eco-sustainable agriculture. Due to the health-promoting benefits of echinacea, it is crucial to increase the bioactive ingredients of the Echinacea by undertaking breeding and other conventional approaches ${ }^{[13]}$. The significant variations present in caffeic acid as well as alamedas in the different developmental stages of echinacea was determined. ${ }^{[14]}$ The information regarding the effect of the mycorrhizal inoculation on the biochemical composition of the different Echinacea species is not available in detail. Therefore, here we determined the changes in the biochemical composition of Echinacea as a result of mycorrhizal inoculation as they are environmentally friendly, economical and sustainable.

\section{Materials and Methods}

\section{Experimental setup and bioinoculation}

The present experiment was conducted in the Department of Botany, Kurukshetra University, Kurukshetra in the open field condition from April 2020 to August 2020. An experiment was set up in a complete randomized block design (CRBD). Plants were grown on the moist filter paper and 10 days seedling was then transferred to the field containing soil:sand mixture whose physical and chemical composition is as follows. ${ }^{[15,16]}$

A soil culture of AMF, Glomus mosseae (having 82-86\% colonized root pieces and 620-630 AM spores per $100 \mathrm{~g})$ and Gigasporagigantean (having 70-74\% colonized root pieces and 500-520 AM spores per $100 \mathrm{~g})$. Each AMF were then mass multiplied using sterile sand soil mixture (1:3) and Maize as host for 90 days, in greenhouse 
conditions. AMF are propagated as endomycorrhizal species as they are obligate symbiont. The native density of mycorrhizal spores in the experimental site was $24.5 \pm 7.09$ per $10 \mathrm{~g}$ soil, which was counted by the gridline intersect method. ${ }^{[17]}$

Bacillus subtilis (MTCC 1305) and Pseudomonas fluorescens (MTCC No. 103) were obtained from the Institute of Microbial Technology (Imtech), Chandigarh, India. Both of them were cultures in nutrient broth medium $(\mathrm{NaCl}$, Peptone, Beef extract)and incubated at $32^{\circ} \mathrm{C}$ for $48 \mathrm{hrs}$ to get a colony rate of $1 \times 10^{-11}$ colony $\mathrm{ml}^{-1}$ and $1 \times 10^{-9}$ colony $\mathrm{ml}^{-1}$, respectively.

\section{Field preparation}

First of all, the field of $7.5 \times 10$ feet was ploughed thoroughly for proper aeration and indigenous spores were counted before the planting of seedlings. Six flowerbeds of $1 \times 1 \mathrm{~m}$ was made with a $10 \mathrm{~cm}$ alleyway as shown below. Fifteen + fifteen seedlings each of $E$. purpurea, E. angustifolia, E. pallida were then planted at 14 inches' distance which was regularly watered by drip irrigation method. For each species, one flowerbed is kept as a control in which no inoculation was added. Still, other fields were subjected to consortium treatment as it was proven that consortium treatment enhances the growth and development of flowering plants. ${ }^{[18,19]}$

Inoculation contains $70-72 \%$ G. mosseae colonized maize roots $(\square 1 \mathrm{~cm})$ and 610630 spores (per $100 \mathrm{~g}$ of maize rhizospheric soil), $65-67 \%$ G. gigantean colonized maize roots ( $\square 1 \mathrm{~cm}$ ) and 580600 spores (per $100 \mathrm{~g}$ of maize rhizospheric soil), $B$. subtilis and $P$. fluorescence. First bacterial inoculation was given during the planting of seedlings in the flowerbed by merely dipping the roots in the respective broth media for $10 \mathrm{~min}$. After 10-13 days when plantlets affirm their roots (c.a. 10 $\mathrm{mm}$ ), the second treatment of G. mosseae and $G$. gigantean was given by placing extra maize rhizospheric soil around the roots, to confirm the inoculation. Similarly, the second treatment of $B$. subtilis and $P$. fluorescence was given by respective sprinkling media around the roots.

\section{Parameters assessments}

After 90 days of inoculum (DOI), out of fifteen plants from each plot, 10 plants were selected randomly for assessment. Morphological characters and biochemical as well as physiological parameters like whole plant dry weight, total chlorophyll, carotenoid, nitrogen, phosphorus, potassium, phenolics content, root essential oil, antioxidant activity and mycorrhization are assessed.

Total dry weight was calculated by carefully uprooting the plant, weighing it and then oven-dry them at $55^{\circ} \mathrm{C}$ for 2 days, finally, by subtracting fresh weight with dry weight.

Chlorophyll content was determined using optical absorbance at 620 and $940 \mathrm{~nm}$. Whereas the total carotenoid content was determined by the Arnon'smethod. ${ }^{[20]}$. While total NPK content was calculated by the Bandyopadhyay et al., method. ${ }^{[21]}$.

\section{Statistical analysis}

Analysis of Variance (ANOVA) was conducted and one-way ANOVA was used to detect the differences among means of each treatment using SPSS (11.5 version) software package. ${ }^{[28]}$.

The results of the experiment were analyzed for studying parameters between control and microbial-inoculated plants and the significance of differences was calculated using least significant differences (LSD) LSD $(P \leq 0.05)$. 


\section{Results and Discussion}

The findings of the experiment are about Biological traits; the bio-Physiological attributes mycorrhization pattern of three different species of echinacea is illustrated in [Table 1].

\section{Biological traits}

In this experiment, biological traits, total plant dry matter, total chlorophyll, total carotenoid, total $\mathrm{N}$ content, total $\mathrm{P}$ content, and total $\mathrm{K}$ content were found increased over control [Table 1]. The consortium showed a significant effect on the biological traits of Echinacea spp. The highest plant dry matter was higher under E. angustifolia $(49.29 \mathrm{~g})$ followed by E.purpurea and E. pallid [Table 1]. Total chlorophyll content was higher under E. purpurea $\left(52.79 \mathrm{mg} \mathrm{g}^{-1}\right)$ than the $E$. angustifolia $\left(49.29 \mathrm{mg} \mathrm{g}^{-1}\right.$ ) and E. pallida (41.29 $\mathrm{mg} \mathrm{g}^{-1}$ ).Total carotenoid was higher under $E$. angustifolia $\left(25.64 \mathrm{mg} \mathrm{g}^{-1}\right)$ followed by $E$. purpurea $\left(26.84 \mathrm{mg} \mathrm{g}^{-1}\right)$ and minimum Cartenoid was found under E.pallida $(23.70$ $\mathrm{mg} \mathrm{g}^{-1}$ ) [Table 1]. Total $\mathrm{N}$ content was found higher under consortium over control. The highest $\mathrm{N}$ content was under $E$. purpurea
(2.96\%) followed by E. angustifolia (2.58\%) and E. apallia $(1.94 \%)$ [Table 1]. Total $\mathrm{P}$ and $\mathrm{K}$ content were significantly higher under consortium than the control plant [Table 2]. The highest $\mathrm{P}$ was higher under $E$. purpurea $(0.88 \mathrm{ppm})$ followed by E.angustifolia $(0.77$ ppm) and E. pallida has lowest $\mathrm{P}$ content [Table 1]. The same result was found for $\mathrm{K}$ content in echinacea species over the control treatment. Highest $\mathrm{K}$ was found under $E$. purpurea $(1.83 \mathrm{ppm})$ followed by $E$. angustifolia (1.79 ppm) and lowest under E.pallida (1.42 ppm) [Table 1]. After 90 days of inoculum, all the plants having bioinoculants showed better results as compared to control. According to the results, incorporating mycorrhizae in echinacea species the mineral composition was increased.

AMF was very significant for improvising the biochemical composition. Applying plant growth-promoting rhizobacteria (PGPR) and mycorrhizal fungi improve the traits and yield in E. purpurea. The mixture of bacteria with mycorrhizal inoculum and shoots was treated with biofertilizers to enhance the biochemical composition. ${ }^{[29]}$

Table.1 Composition of soil used for the cultivation of Echinacea species.

\begin{tabular}{|c|c|}
\hline Component & Value \\
\hline Soil & $60.5 \%$ \\
\hline Sand & $19.5 \%$ \\
\hline Clay & $12.2 \%$ \\
\hline Silt & $7.8 \%$ \\
\hline $\mathrm{pH}$ & 6.7 \\
\hline Organic $\mathrm{matter}(\mathrm{g} / \mathrm{kg})$ & 0.78 \\
\hline EC $(\mathrm{dS} / \mathrm{m})$ & 0.45 \\
\hline Available N $(\mathrm{mg} / \mathrm{kg})$ & 15.02 \\
\hline Available $\mathrm{P}(\mathrm{mg} / \mathrm{kg})$ & 7.04 \\
\hline Available K $(\mathrm{mg} / \mathrm{kg})$ & 87.11 \\
\hline
\end{tabular}


Table.2 Changes in the total plant dry matter $(\mathrm{g})$ and biochemical parameters of 3different echinacea species with/without mycorrhizal inoculation.

\begin{tabular}{|c|c|c|c|c|}
\hline Traits & Control & $\begin{array}{c}\text { Consortium } \\
\text { (Glomus mosseae+Giga } \\
\text { sporagigantean+ Pseudomonas } \\
\text { fluorescence+ } \\
\text { Bacillus subtilis) }\end{array}$ & ANOVA $(2,27)$ & $\begin{array}{c}\text { LSD } \\
(\boldsymbol{P} \leq \mathbf{0} . \\
\mathbf{0 5})\end{array}$ \\
\hline & \multicolumn{4}{|c|}{ Echinacea angustifolia } \\
\hline $\begin{array}{l}\text { Total plant dry matter } \\
(\mathrm{g})\end{array}$ & $11.653 \pm 3.121_{t}^{\mathrm{b}}$ & $49.238 \pm 3.463^{\mathrm{a}}$ & 1.012 .435 & 2.176 \\
\hline $\begin{array}{l}\text { Total chlorophyll (mg } \\
\left.\mathrm{g}^{-1} \mathrm{FW}\right)\end{array}$ & $21.464 \pm 1.667^{b}$ & $49.296 \pm 1.726^{\mathrm{a}}$ & 2.605 .044 & 1.294 \\
\hline $\begin{array}{c}\text { Total carotenoid (mg } \\
\left.\mathrm{g}^{-1} \mathrm{FW}\right)\end{array}$ & $11.045 \pm 0.778^{b}$ & $25.645 \pm 0.895^{\mathrm{a}}$ & 3.580 .926 & 0.574 \\
\hline Total $\mathrm{N}$ content $(\%)$ & $1.882 \pm 0.264^{\mathrm{b}}$ & $2.583 \pm 0.344^{\mathrm{a}}$ & 319.115 & 0.201 \\
\hline Total $\mathrm{P}$ content $(\mathrm{ppm})$ & $0.304 \pm 0.113^{b}$ & $0.778 \pm 0.123^{\mathrm{a}}$ & 132.912 & 0.091 \\
\hline \multirow{2}{*}{ Total $\mathrm{K}$ content (ppm) } & $0.941 \pm 0.289^{\mathrm{b}}$ & $1.799 \pm 0.151^{\mathrm{a}}$ & 240.418 & 0.155 \\
\hline & \multicolumn{4}{|c|}{ Echinacea purpurea } \\
\hline $\begin{array}{c}\text { Total plant dry matter } \\
(\mathrm{g})\end{array}$ & $10.753 \pm 2.458^{b_{t}}$ & $45.738 \pm 3.878^{\mathrm{a}}$ & 787.304 & 2.432 \\
\hline $\begin{array}{l}\text { Total chlorophyll (mg } \\
\left.\mathrm{g}^{-1} \mathrm{FW}\right)\end{array}$ & $23.793 \pm 3.609^{b}$ & $52.796 \pm 3.818^{\mathrm{a}}$ & 732.364 & 2.783 \\
\hline $\begin{array}{l}\text { Total carotenoid (mg } \\
\left.\mathrm{g}^{-1} \mathrm{FW}\right)\end{array}$ & $12.145 \pm 2.168^{b}$ & $26.845 \pm 2.096^{\mathrm{a}}$ & 554.129 & 1.597 \\
\hline Total $\mathrm{N}$ content $(\%)$ & $2.107 \pm 0.503^{b}$ & $2.9631 \pm 0.554^{\mathrm{a}}$ & 51.816 & 0.396 \\
\hline Total $\mathrm{P}$ content (ppm) & $0.305 \pm 0.097^{\mathrm{b}}$ & $0.887 \pm 0.095^{\mathrm{a}}$ & 225.479 & 0.072 \\
\hline \multirow[t]{2}{*}{ Total K content (ppm) } & $0.934 \pm 0.292^{b}$ & $1.839 \pm 0.439^{\mathrm{a}}$ & 27.366 & 0.279 \\
\hline & \multicolumn{4}{|c|}{ Echinacea pallida } \\
\hline $\begin{array}{c}\text { Total plant dry matter } \\
(\mathrm{g})\end{array}$ & $10.353 \pm 2.231^{\mathrm{b}} \ddagger$ & $40.079 \pm 3.632^{\mathrm{a}}$ & 687.314 & 2.258 \\
\hline $\begin{array}{l}\text { Total chlorophyll (mg } \\
\left.\mathrm{g}^{-1} \mathrm{FW}\right)\end{array}$ & $19.603 \pm 1.983^{b}$ & $41.296 \pm 3.241^{\mathrm{a}}$ & 68.063 & 1.093 \\
\hline $\begin{array}{l}\text { Total carotenoid (mg } \\
\left.\mathrm{g}^{-1} \mathrm{FW}\right)\end{array}$ & $9.249 \pm 0.889^{b}$ & $23.707 \pm 0.855^{\mathrm{a}}$ & 2.602 .873 & 0.653 \\
\hline Total $\mathrm{N}$ content $(\%)$ & $0.939 \pm 0.305^{\mathrm{b}}$ & $1.947 \pm 0.364^{\mathrm{a}}$ & 42.460 & 0.251 \\
\hline Total $\mathrm{P}$ content $(\mathrm{ppm})$ & $0.243 \pm 0.101^{b}$ & $0.697 \pm 0.098^{\mathrm{a}}$ & 218.137 & 0.075 \\
\hline Total K content (ppm) & $0.622 \pm 0.269^{b}$ & $1.424 \pm 0.335^{\mathrm{a}}$ & 26.115 & 0.243 \\
\hline
\end{tabular}

\pm - Standard deviation; $\$$ - values in column followed by the same letter are not significantly different; $p \leq 0.05$ - LSD (least significant difference test); FW- Fresh Weight; ppm- Parts per million

The phenolic compound was higher in $E$. purpurea followed by $E$. angustifolia and $E$. pallida. ${ }^{[30]}$ There was variability among echinacea species. for biochemical composition. Variable positive effects of mycorrhiza were found for different varieties of echinacea. Similar results were found in root colonization by mycorrhizal fungi with $E$. 
purpurea. Increasing root colonization with the help of biofertilizers helps to improve the phenolic compound of plant roots such as cynarin, cichoric and caftaric acid. ${ }^{[31]}$ Soil fertilization with the biochemical fertilizers such as AMF and Pseudomonas species have improved growth and yield components. ${ }^{[32-36]}$ AMF and PFB were more useful for increasing plant nutrients, improving leaf relative water content and decreased ion leakage. ${ }^{[37]}$ E.angustifolia showed increased echinacoside content by applying K. In all addition to increasing absorption of nutrients, development by plant hormones, controlling plant pathogens and some other factors. ${ }^{[38,39]}$

AMF improved the host plants in many ways such as the uptake of phosphorus and other nutrients, increased plant growth, plant height, leaf area, freshldry weight of shoots and roots. ${ }^{[40,41]}$

From the present experimentation, it can be concluded that bioinoculants modify the phytohormones, water uptake efficiency and photosynthetic activity. This results in better plant growth. By this, we can draw attention toward the commercialization of plant products, mostly medicinal plants and their products, as this microbial association is sustainable and beneficial, not only for plants but for the soil ecosystem too. This produces better place growth and improved bio physiochemical parameters. The results of the mycorrhizal association were significant for plant growth plus improved biophysiochemical characteristics when compared with the management plants.

\section{References}

1. Kumar K M and Ramaiah S. Pharmacological importance of Echinacea purpurea. International Journal of Pharma and Bio Sciences 2011;2:304-314.

2. Letchamo W, Polydeonny L V, Gladisheva N O, Arnason T J, Livesey J and Awang D V C.
Factors affecting Echinacea quality. Trends in new crops and new uses 2002; 514-521.

3. Foster S. Herbal Remedies: Echinacea: The Cold and Flu Remedy. Alternative and Complementary Therapies.1995;1:254-257.

4. Gangemi S, Minciullo P L, Miroddi M, Chinou I, Calapai G and Schmidt R J. Contact dermatitis as an adverse reaction to some topically used European herbal medicinal products-Part 2: Echinacea purpureaLavandula angustifolia. Contact dermatitis. 2015;72: 193-205.

5. Li T S C snf Wang L C H. Physiological components and health effects of ginseng, echinacea and seabuck thorn. Functional foods, biochemical and processing aspects. 1998; 1:329.

6. Kaushik P, Andújar I, Vilanova S, Plazas M, Gramazio P, Herraiz F J, et al., Breeding vegetables with increased content in bioactive phenolic acids. Molecules. 2015;20(10):18464-81.

7. Sabra A, Daayf F and Renault S. Differential physiological and biochemical responses of three Echinacea species to salinity stress. Scientia Horticulturae 2012;135:23-31.

8. Chicca A, Adinolfi B, Martinotti E, Fogli S, Breschi M C, Pellati Fand Nieri P. Cytotoxic effects of Echinacea root hexanic extracts on human cancer cell lines. Journal of ethnopharmacology 2007;110:148-153.

9. Sinha S. Ascertaining the Paradigm of Secondary Metabolism Enhancement through Gene Level Modification in Therapeutic Plants. Journal of Young Pharmacists. 2019;11(4):337-43.

10. Snyder K M, Baskin J M and Baskin C C. Comparative ecology of the narrow endemic Echinacea tennesseensis and two geographically widespread congeners: relative competitive ability and growth characteristics. International Journal of Plant Sciences 1994;155: 57-65.

11. Brar N S, Saini D K, Kaushik P, Chauhan J, Kamboj N K. Directing for Higher Seed Production in Vegetables. Agronomy Climate Change \& Food Security. IntechOpen; 2019.

12. Malhi G S, Kaur M, Kaushik P, Alyemeni M N, Alsahli A A, Ahmad P. Arbuscular mycorrhiza in combating abiotic stresses in 
vegetables: An eco-friendly approach. Saudi J Bio Sci. 2021;28(2):1465-76.

13. Kindscher K, Price D M and Castle L. Resprouting of Echinacea angustifolia augments sustainability of wild medicinal plant populations. Economic Botany 2008;62:139-147.

14. Yadav A, Saini I, Kaushik P, Ahmad Ansari M, Rashid Khan M, Haq N. Effects of arbuscular mycorrhizal fungi and Psolubilizing Pseudomonas fluorescence (ATCC-17400) on morphological traits and mineral content of sesame. Saudi J Bio Sci. 2021;28(5):2649-54.

15. Black C A, Evans D O. Ensminger L E, White J L, Clark F E and Dinauer R C. Methods of soil analysis. part 2. Chemical and microbiological properties. 2nd Ed. Soil Sci., Soc. of Am. Inc. Publ., Madison, Wisconsin, U.S.A.1982.

16. 16.Kaushik P. Classification of Indian States and Union Territories based on their Soil Macronutrient and Organic Carbon Profiles. bioRxiv2020.

17. Sharma M, Saini I, Kaushik P, Aldawsari MM, Balawi TA, Alam P. Mycorrhizal fungi and Pseudomonas fluorescens application reduces root-knot nematode (Meloidogyne javanica) infestation in eggplant. Saudi J Bio Sci. 2021;28(7):3685-91.

18. Sharma M, Kaushik P, Chaturvedi P. Enumeration, Antagonism and Enzymatic Activities of Microorganisms Isolated from Railway Station Soil. bioRxiv. 2018; 454595.

19. Saini I. Aggarwal A. and Kaushik P. Influence of biostimulants on important traits of Zinnia elegans Jacq. under open field conditions. Int. J. Agron., 2019; 3082967.

20. Arnon D I. Copper enzymes in isolated chloroplasts. Polyphenoloxidase in Beta vulgaris. Plant Physiol 1949; 24:1.

21. Bandyopadhyay K, Aggarwal P, Chakraborty D, Pradhan S, Narayan Garg R, Singh R. Practical Manual on Measurement of Soil Physical Properties Practical. Division of Agricultural Physics, IARI, New Delhi2012; 102-125.

22. Farhat M B, Chaouch-Hamada R, Sotomayor J A, Landouisi A, Jordán MJ Antioxidant potential of Salvia officinalis L. residues as affected by the harvesting time. Ind Crop
Prod 2014;54:78-85.

23. Wang B, Huang Q Y, Venkitasamy C, Chai HK, Gao H, Cheng N, Cao W, Lv X A, Pan Z L. Changes in phenolic compounds and their antioxidant capacities in jujube (Ziziphus jujuba Miller) during three edible maturity stages. L W T - Food Sci Technol 2016;66:56-62.

24. Re R, Pellegrini N, Proteggente A, Pannala A, Yang M, Rice-Evans C. Antioxidant activity applying an improved ABTS radical cation decolorization assay. Free Radi Bio Med.1999;26:1231-1237.

25. Mazza G and Cottrell T, Volatile components of roots, stems, leaves and flowers of Echinacea species. J. Agric. Food. Chem 1999;47:3081- 3085.

26. Giovannetti M, Mosse B. An evaluation of techniques for measuring vesicular arbuscular mycorrhizal infection in roots. New Phytol 1980;84:489-500.

27. Phillips J M, Hayman D S. Improved procedures for clearing roots and staining parasitic and vesicular-arbuscular mycorrhizal fungi for rapid assessment of infection. Trans. Brit. Mycol. Soc 1970;55:16-18.

28. Nie N H, Bent D H, Hull C H. SPSS: Statistical Package for the Social Sciences, McGraw-Hill, New York, USA1975.

29. Hajagha R I, Kirici S, Tabrizi L, Asgharzadeh A and Hamidi A. Evaluation of Growth and Yield of Purple Coneflower (Echinacea purpurea L.) in Response to Biological and Chemical Fertilizers. Journal of Agricultural Science 2017..

30. Pellati F, Benvenuti S, Melegari Mand Lasseigne T. Variability in the composition of anti-oxidant compounds in Echinacea species by HPLC. Phytochemical Analysis: An International Journal of Plant Chemical and Biochemical Techniques 2005;16:77-85.

31. Attarzadeh $M$, Balouchi $H$, Rajaie $M$, Dehnavi M Mand Salehi A. Improving growth and phenolic compounds of Echinacea purpurea root by integrating biological and chemical resources of phosphorus under water deficit stress. Industrial Crops and Products.2020;154:112763.

32. Saini I, Kaushik P, Al-Huqail A A, Khan F, Siddiqui $M \quad H$. Effect of the diverse 
combinations of useful microbes and chemical fertilizers on important traits of potato. Saudi Journal of Biological Sciences. 2021;28(5):2641-8.

33. Kaushik P, Saini D K. Silicon as a vegetable crops modulator-A review. Plants. 2019;8(6):148.

34. Saini I, Himanshi, Rani K, Gill N, Sandhu K, Bisht $\mathrm{N}$, et al., Significance of Arbuscular Mycorrhizal Fungi for Acacia: A Review. Pak J Biol Sci. 2020 Jan;23(10):1231-6.

35. Kumar V, Singh A and Sharma S. Yield and economics of Withania somnifera influenced by dual inoculation of Azotobacter chroococcum and Pseudomonas putida, Turk. J. Biol 2009;33:219-223.

36. Berti M, Wilckens R, Fischer Sand Hevia F. Effect of harvest season, nitrogen, phosphorus and potassium on root yield, echinacoside and alkylamides in Echinacea angustifolia L., Chile. Possibilities and Limitations of Medicinal and Aromatic Plant. Int. Con. Medicin. Aroma. P 2001;576 :303-310.

37. Kaushik P, Sandhu O S, Brar NS, Kumar V, Malhi G S, Kesh H, et al., Soil Metagenomics: Prospects and Challenges. Mycorrhizal Fungi - Utilization in Agriculture and Industry [Internet]. 2020 Sep 4 [cited 2020 Sep 18]; Available from: https://www.intechopen.com/online-first/soilmetagenomics-prospects-and-challenges
38. Saini I, Aggarwal, A, Kaushik P. Inoculation with mycorrhizal fungi and other microbes to improve the morpho- physiological and floral traits of Gazania rigens (L.) gaertn. Agriculture 2019; 51.

39. Saini I, Himanshi, Rani K, Gill N, Sandhu K, Bisht N, Kumar T, Kaushik P. Significance of Arbuscular Mycorrhizal Fungi for Acacia: A Review. Pakistan Journal of Biological Sciences 2020;23:1231-1236.

40. Arumugam R, Rajasekaran S, Nagarajan S M. Response of Arbuscular mycorrhizal fungi and Rhizobium inoculation on growth and chlorophyll content of Vigna unguiculata (L.) Walp Var. Pusa 151. J. Appl. Sci. Environ. Manag 2010; 14.

41. Renella G, Egamberdiyeva D, Landi L, Mench M, Nannipieri P. Microbial activity and hydrolase activities during decomposition of root exudates released by an artificial root surface in Cd-contaminated soils, Soil Biol. Biochem 2006;38:702-708.

42. Bijalwan P, Jeddi K, Saini I, Sharma M, Kaushik P, Hessini K. Mitigation of saline conditions in watermelon with mycorrhiza and silicon application. Saudi J Bio Sci 2021;28(7):3678-84.

43. Saini I, Aggarwal A, Kaushik P. Influence of Biostimulants on Important Traits of Zinnia elegans Jacq. under Open Field Conditions. Int J Agronomy. 2019; e3082967.

\section{How to cite this article:}

Asha Sharma, Ishan Saini and Bandi Arpitha Shankar. 2021. Effect of the Application of Mycorrhizal Inoculation on Different Species of Echinacea. Int.J.Curr.Microbiol.App.Sci. 10(08): 99-106. doi: https://doi.org/10.20546/ijcmas.2021.1008.013 